\title{
FIRST RECORD OF COELOPISTHIA FORSTER (CHALCIDOIDEA: PTEROMALIDAE) FROM THE ORIENTAL REGION WITH THE DESCRIPTION OF A NEW SPECIES FROM SRI LANKA
}

\author{
P.M. Sureshan
}

Estuarine Biological Station, Zoological Survey of India, Gopalpur-on-sea, Orissa 761002, India

Email: samanyu2003@yahoo.com

\begin{abstract}
Coelopisthia Forster (Hymenoptera: Pteromalidae) is reported for the first time from the Oriental Region with the description of a new species from Sri Lanka. Affinities of the new species with related species is discussed.
\end{abstract}

\section{KEYWORDS}

Chalcidoidea, Coelopisthia, Hymenoptera, new species, oriental region, Pteromalidae, Sri Lanka

\section{AbBreviations}

F1-F6 - Funicular segments 1 to 6; OOL - Ocellocular distance; POL - Postocellar distance; SMV - Submarginal vein; MV Marginal vein; PMV - Postmarginal vein; STV - Stigmal vein; T1 - Gastral tergite 1

Coelopisthia Forster is a rare genus of Pteromalidae in the subfamily Pteromalinae, the species of which are only known from Palearctic and Nearctic regions of the world. Altogether 12 species are known under the genus, most of them hail from the northern temperate zone (Noyes, 2001). Host records of Coelopisthia species are scarce and as per the available biological information they are primary parasites of various Lepidoptera (moths) mainly of family Tortricidae (Askew, 1980; Boucek \& Rasplus, 1991; Boucek \& Heydon, 1997). One new species of Coelopisthia is described here from Sri Lanka based on the collection received from the Bohart Museum of Entomology, University of California that was made available for my study by the kind courtesy of Dr. Steven L. Heydon.

\section{Coelopisthia lankana sp. nov.}

(Figures 1-5)

\section{Material Examined}

Holotype: Female, 23-30.viii.1999, Rantembe Sanctuary, Viet. Randenigala, Kandy dist., Central Province, Sri Lanka, $07^{0} 13^{\prime} \mathrm{N}$ \& $080^{\circ} 57^{\prime}$ E, coll. M.T.M \& J. Wasbauer (in Bohart Museum of Entomology, University of California, USA), loan number 203035.

\section{Etymology}

The species is named after the country of origin.

\section{Diagnositc characters}

Female: Length $2.4 \mathrm{~mm}$. Head and thorax dark metallic bluishgreen, almost black on head; gaster dark brown with slight metallic blue reflection dorsally on T1, ovipositor testaceous; legs with coxae concolorous with thorax, remainder brownishyellow; mandibles brown; eyes pale cupreous; antenna with scape, pedicel and anelli testaceous, remainder brown with tips of club paler; tegulae pale brown, wings hyaline, veins pale testaceous.
Head: (Fig. 1) Moderately reticulate with small white pubescence, almost $2 \mathrm{x}$ as broad as long in dorsal view; temple half as long as the eye; occipital carina fine but distinct; eyes not hairy; POL 1.75x OOL; head in front view $1.2 \mathrm{x}$ as broad as high; genae almost straight; malar sulcus fine; eyes separated $1.3 \mathrm{x}$ by their height (measured at middle of face) their inner orbits diverging ventrally; malar space about $0.4 \mathrm{x}$ the height of an eye; right mandible with four and left with three teeth. Head in profile with face receding below toruli and forming an angle of about $130^{\circ}$ with the frons; clypeus finely reticulate with elongated areoles, anterior margin with two teeth; scrobe deep, reaching front ocellus; lower edges of antennal toruli little above lower margin of eyes; antennae (Fig. 2) with scape not reaching median ocellus, about one diameter of median ocellus away, little shorter than height of an eye (9:10), combined length of pedicellus plus flagellum $0.9 \mathrm{x}$ breadth of head, pedicellus (in profile) about 2.6x as long as broad, almost equal to anelli and F1 combined, first anellus little shorter than second, second anellus little wider; maximum width of funicle $1.25 \mathrm{x}$ pedicellus in profile, F1 as broad as pedicellus, little longer than wide, F2 little longer than F1, F3 and F4 as long as F2, F5 and F6 little shorter than F4, club little broader than funicle, bluntly pointed, as long as three preceding segments combined; sensillae rather short, in a single row on each funicular and club segments.

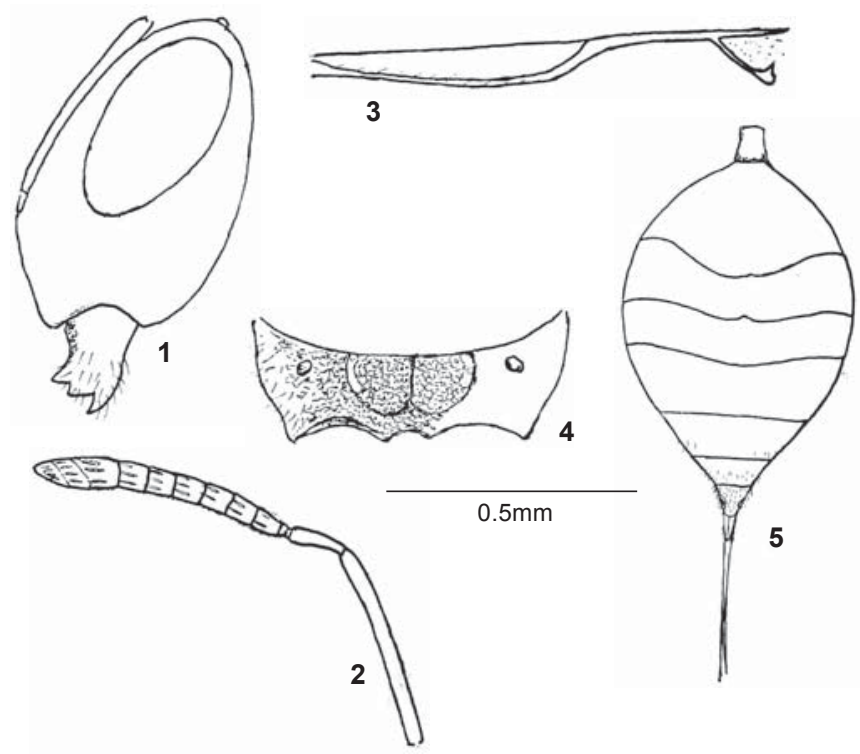

Figures 1-5. Coelopisthia lankana sp. nov. (Female). 1 - Head in profile; 2 - Antenna; 3 - Forewing venation; 4 - Propodeum in dorsal view; 5 - Gaster in dorsal view

(c) Zoo Outreach Organisation; www.zoosprint.org anuary 2006; Date of publication 21 February 2006 
Thorax: (Fig. 1) 1.23x as long as broad, collar not margined anteriorly without smooth strip posteriorly. Mesoscutum 2.4x as broad as long, moderately reticulate. Scutellum $1.14 \mathrm{x}$ as long as mesoscutum, slightly wider than long; similarly reticulate as on mesoscutum, frenal area marked by finer reticulation. Propodeum (Fig. 4) medially $0.56 \mathrm{x}$ as long as scutellum, median carina and plicae complete, median area finely but distinctly reticulate, $1.8 \mathrm{x}$ as broad as long; nucha small, fine; spiracular sulci not distinct; spiracles large, round, separated by a distance less than their diameter from hind margin of metanotum; callus finely reticulate, moderately hairy. Legs slender, hind tibial spur slightly shorter than breadth of hind tibia at its apex. Forewing (Fig. 3) 2.12x as long as broad, pubescence sparse, hairs very short, margin without apical fringe, speculum open below, costal cell hairy towards the tip only, stigmal vein straight. Relative lengths of SMV, MV, PMV, and STV as 20:9:6:5.5.

Gaster: (Fig. 5) Petiolate, petiole smooth, posteriorly little wider, about $1.3 \mathrm{x}$ as long as broad; gaster $1.7 \mathrm{x}$ as long are broad in dorsal view, elongatedly ovate, $1.4 \mathrm{x}$ as long as thorax; $\mathrm{T} 1$ occupying $0.33 \mathrm{x}$ total length, hind margin slightly produced.

\section{Remarks}

This species closely resembles $C$. caledonica Askew in general morphology but differs from it in having clypeus bidentate, antenna with first anellus small, second not much broad, F1 elongate, pronotum without a smooth strip posteriorly, median area of propodeum 1.8x as broad as long, gaster with hind margin of $\mathrm{T} 1$ produced (in caledonica clypeus almost straight anteriorly, antenna with both anelli broad and large, F1 quadrate, pronotum with a smooth shiny strip psoteriorly, propodeum with median area $3 \mathrm{x}$ as broad as long and gaster with hind margin of T1 nearly straight). In facial features this new species readly resembles $C$. pachycera Masi i.e. face receding from frons at angle of $130^{\circ}$ so that in frontal view the lower edges of toruli lie much nearer to lower edges of eyes than the anterior margin of the clypeus, but differs in having antenna with funicular segments 3-5 not strongly transverse and flagellum not about $2 \mathrm{x}$ as broad as long.

\section{REFERENCES}

Askew, R.R. (1980). The European species of Coelopisthia (Hymenoptera: Pteromalidae). Systematic Entomology 5: 1-6. Boucek, Z. and J.Y. Rasplus (1991). Illustrated Key to the WestPalearctic Genera of Pteromalidae (Hymenoptera: Chalcidoidea). Institut National de la Recherche Agronomique, Paris, 140pp.

Boucek, Z. and S.L. Heydon (1997). Pteromalidae, pp. 541-692. In: Gibson et al. (Eds.) 1997. Annotated Keys to the Genera of Nearctic Chalcidoidea (Hymenoptera). NRC Research press, Ottawa, Canada. Noyes, J.S. (2001). Interactive Catalogue of World Chalcidoidea 2001 (CD-Rom). Dicks.Yu, Bentall Centre, Canada.

\section{ACKNOWLEDGEMENTS}

The author is grateful to the Director, Zoological Survey of India, Kolkatta and the Officer-in-charge, Zoological Survey of India, Estuarine Biological Station, Gopalpur-on-sea, Orissa for providing facilities and encouragement. He is also grateful to Dr. Steven L. Heydon, Bohart Museum of Entomology, University of California, USA, for providing the specimen on loan and relevant literature on Coelopisthia.

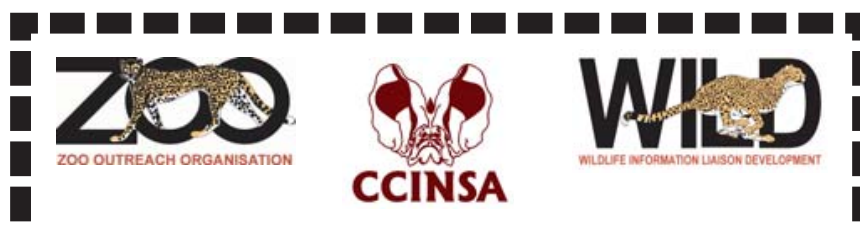

South Asian
Bat Monitoring Programme

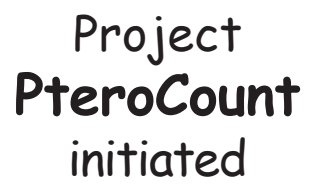

If you are interested in volunteering

for this exciting project, please visit us at

www.pterocount.org

or write to us

Volunteers who have enrolled can visit www.pterocount.org for more details. Individual mailers are being sent to all participants with an Overview and Data Form

Project PteroCount
c/o CCINSA, ZOO, WILD
29-1 Bharathi Colony, Peelamedu
Coimbatore, Tamil Nadu 641004
India
Email: contact@pterocount.org
pterocount@yahoo.com
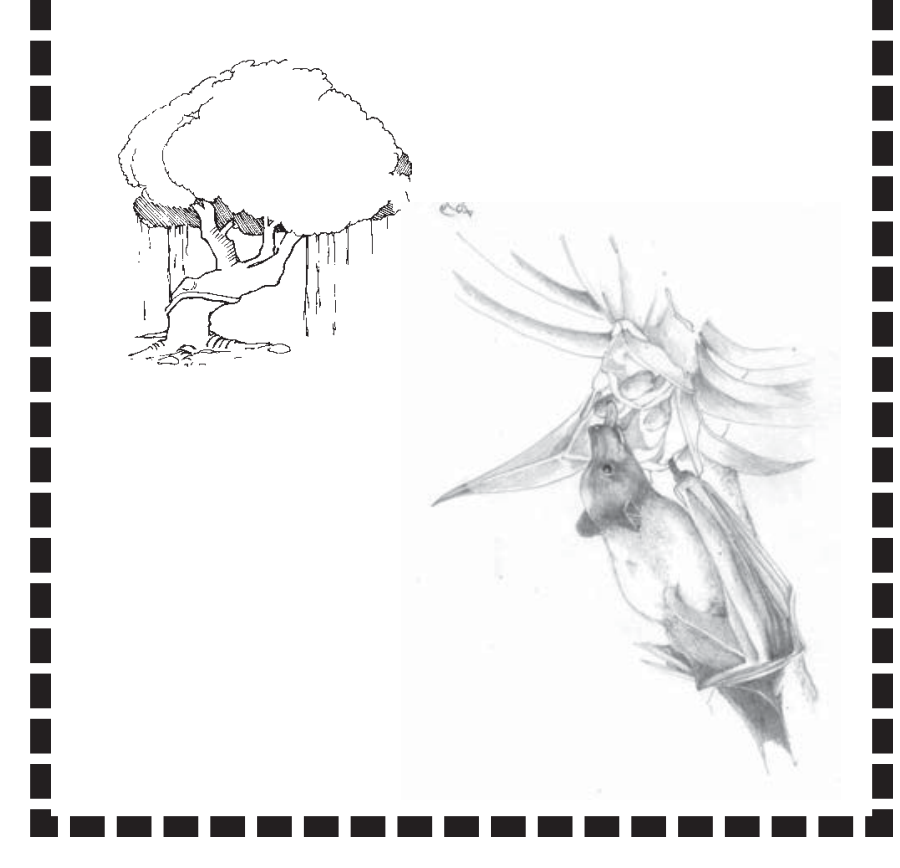